\title{
Microsatellite loci and paternity analysis in Nubia and Boer goats
}

\author{
Loci de microsatélites y análisis de paternidad en cabras Nubia y Boer
}

\author{
A Luna-González ${ }^{\mathrm{a}, \mathrm{b}}$, S Hernández-Arteaga ${ }^{\mathrm{b}}$, M Sánchez-Garza ${ }^{\mathrm{b}}$, R López-Revilla ${ }^{\mathrm{b}}$, \\ L Medina-Esparza ${ }^{a}, \mathbf{C}$ Cruz-Vázquez ${ }^{*}$ \\ anstituto Tecnológico El Llano, Aguascalientes, México. \\ bDivisión de Biología Molecular, Instituto Potosino de Investigación Científica y Tecnológica, \\ San Luis Potosí, México.
}

\begin{abstract}
RESUMEN
Los loci SRCRSP (Small Ruminant Collaborative Research Support Program) son secuencias de microsatélites polimórficos de 100-300 pares de bases de dinucleótidos repetidos que pueden ser amplificados por la reacción en cadena de la polimerasa (PCR). Los alelos de un determinado locus son los productos de PCR de longitud única amplificados con iniciadores específicos. Los loci SRCRSP se han utilizado para identificar individuos, pero no para determinar la paternidad en el ganado caprino. En el presente trabajo se reporta el desarrollo de un método para evaluar la paternidad en caprinos mediante el análisis del polimorfismo de loci SRCRSP en un rebaño de 20 animales, que incluía nueve de raza Nubia y 11 Boer. Se amplificaron 36 alelos: 6 del SRCRSP-1, 5 del SRCRSP-2, 4 del SRCRSP-3, 5 del SRCRSP-4, 5 del SRCRSP-5, 6 del SRCRSP-6 y 5 del SRCRSP-9. Cuatro alelos aparecieron exclusivamente en el grupo Nubia, mientras que sólo ocho en el grupo Boer. El análisis del polimorfismo llegó a 0.995 de certeza en la exclusión correcta del segundo padre. Los loci descritos en este trabajo podrían ser utilizados para controlar la paternidad así como para identificar a los individuos en ganado caprino.
\end{abstract}

Key words: goats, microsatellites, paternity, SRCRSP alleles.

Palabras clave: cabras, microsatélites, paternidad, alelos SRCRSP.

\section{INTRODUCTION}

Caprine breeding represents an alternative for meat, milk and fur production mostly in arid, semiarid and mountainous areas of the world due to the rusticity and adaptability of the goat to different environmental and handling conditions. In Mexico, goat breeding is important in the highland regions located in the northern-central part of the country. Caprine livestock in Mexico is composed by animals derived from crosses of different breeds; around $3 \%$ is genetically improved and most flocks are formed by a few animals, increasing the endogamic pressure in each generation. The production system is extensive and as several studs are kept in each flock mating control, recognition of pregnant females and identification of the offspring is prevented (Arbiza 1986).

A precise pedigree information is essential to start genetic improvement programs in order to ensure progress and avoid consanguinity. An effective method to analyze paternity is the use of microsatellite loci which consists of simple repeated and highly variable codominant sequences dispersed through the genome that can be characterized by polymerase chain reaction (PCR) amplification; although microsatellite sequences have been used in goat phylogenetic research there is limited information on these markers

Accepted: 07.12.2011

* Km. 18 carretera Aguascalientes a San Luis Potosí, CP 20330, El Llano, Aguascalientes, México; cruva18@yahoo.com.mx to analyze paternity in goat flocks. Luikart et al (1999) developed a highly reliable method for identification of individuals based on two multiplex amplification systems, each with 11 microsatellite loci, in which eight loci were caprine, nine were bovine and five were ovine. Arevalo et al (1994) used the caprine polymorphic dinucleotide microsatellite loci of the Small Ruminant Collaborative Research Support Program designated SRCRSP-1,-2,-3,4 and -5 , whereas Bhebe et al (1994) used SRCRSP-6, $-7,-8,-9$, and -10 for phylogenetic research in goats and other ruminants.

The aim of this work was to develop and validate a method to assess the paternity in goat flocks through allele polymorphism analysis with seven SRCRSP microsatellite loci.

\section{MATERIAL AND METHODS}

ANIMALS

The animals were selected using a non probabilistic convenience method (Thrusfield 2007) on a control herd with precise mating records. A total of 20 animals were sampled: eight females, eight offsprings and four males. The individuals of the Nubia (four females, four offsprings and one male) and the Boer (four females, four offsprings and three males) included in the study were kept at the Centro de Selección y Reproducción Caprina, Secretaría de Desarrollo Agropecuario, San Luis Potosí, Mexico. The 
female and male of each kid were known with certainty. Eight trios of female, male and kid were formed for the paternity analysis. The interdisciplinary principles and guidelines for the use of animals in research, marketing and education of the New York Academy of Sciences ad hoc committee on animal research were observed to perform this study.

\section{DNA EXTRACTION AND MICROSATELLITE AMPLIFICATION}

DNA samples were obtained during a period of 14 months. Three ml blood samples were drawn from the jugular vein from each animal and placed in tubes with anticoagulant. The DNA Ultraclean Bloodspin kit (MO BIO Laboratories, Burlington, Ontario, Canada) was used for genomic DNA extraction following the manufacturer's instructions. Purified DNA was dissolved in TE $(10 \mathrm{mM}$ Tris, $1 \mathrm{mM}$ EDTA, $\mathrm{pH} 8$ ) and stored at $-20^{\circ} \mathrm{C}$. DNA quantification was performed in a Beckman DU 530 spectrophotometer (Sambrook et al 1989). Microsatellite loci SRCRSP-1, -2, -3, -4 and -5 from Arevalo et al (1994), and Microsatellite loci SRCRSP-6 and SRCRSP-9 from Bhebe et al (1994) were amplified using the corresponding SRCRSP primers set (table 1) purchased from Invitrogen (Carlsbad, CA). Magnesium concentration and annealing temperatures were optimized for each primers set. $\mathrm{MgCl}_{2}$ concentration was $1.5 \mathrm{mM}$ and annealing temperatures were $50^{\circ} \mathrm{C}$ for SRCRSP primers set 1,4 and $9 ; 52^{\circ} \mathrm{C}$ for sets 2 and 6 and $55^{\circ} \mathrm{C}$ for sets 3 and 5 . PCR mixtures contained $25 \mu \mathrm{l}$ with the following components: PCR buffer (20 mM Tris-HCl, pH 8.0); dNTPs, $50 \mu \mathrm{M}$ each; primers, $1 \mu \mathrm{M}$ each; Taq DNA polymerase, $25 \mathrm{mU}$; template DNA, $25 \mathrm{ng}$. Mixtures were incubated in a Techne Touchgene gradient thermocycler with the following program: initial denaturation at $95^{\circ} \mathrm{C}$ for $2 \mathrm{~min}$; 35 cycles with denaturation at $95^{\circ} \mathrm{C}$ for $30 \mathrm{sec}$, annealing at the appropriate temperature for each primer set $\left(50^{\circ} \mathrm{C}, 52^{\circ} \mathrm{C}\right.$ or $\left.55^{\circ} \mathrm{C}\right)$ for $60 \mathrm{sec}$, extension at $70^{\circ} \mathrm{C}$ for $60 \mathrm{sec}$; final extension at $70^{\circ} \mathrm{C}$ for $5 \mathrm{~min}$ (Innis et al 1999). PCR products were separated by electrophoresis in $8 \%$ polyacrylamide gels (acrylamide/bisacrylamide 19:1) (Innis et al 1999) in Protean II chambers (BioRad) which were later stained for $15 \mathrm{~min}$ in ethidium bromide (100 ng/ $\mathrm{ml}) .10 \mu \mathrm{l}$ samples were mixed with $7 \mu$ of loading buffer ( $2 \%$ xylene cianol, $2 \%$ Orange $\mathrm{G}$ and $96 \%$ formamide) for the analysis and subjected to electrophoresis in TBE buffer (0.9 M Tris- $\mathrm{HCl}, 0.88 \mathrm{M}$ boric acid, 2 mM EDTA, $\mathrm{pH}$ 8.0). UV-transiluminated gel images were captured in a Gel Doc EQ (BioRad) photodocumenter equipped with the Quantity One version 4.5. The size of DNA bands was determined by comparison with a 50 bp marker ladder (Fermentas Laboratories, Carlsbad, CA). Bands less than $4 \%$ different in size were considered identical.

Table 1. Information on SRCRSP marker microsatellites.

Información sobre los marcadores microsatélites SRCRSP.

\begin{tabular}{|c|c|c|c|c|}
\hline \multirow{2}{*}{$\begin{array}{c}\text { SRCRSP } \\
\text { marker }\end{array}$} & \multirow{2}{*}{ Primer sequences $\left(5^{\prime}-3^{\prime}\right)$} & \multirow{2}{*}{$\begin{array}{l}\text { Expected } \\
\text { size (bp) }\end{array}$} & \multicolumn{2}{|l|}{ GenBank $^{\mathrm{a}}$} \\
\hline & & & ID & Accession $\mathrm{N}^{\circ}$ \\
\hline \multirow[t]{2}{*}{1} & F- TGCAAGAAGTTTTTCCAGAGC & $130-150$ & $116905423330782211291796407 . B L A S T Q 4$ & L22192 \\
\hline & R-ACCCTGGTTTCACAAAAGG & & & \\
\hline \multirow[t]{2}{*}{2} & F- TGCTGTATCCTGTGTAATATCTT & 151-159 & & \\
\hline & R- GCATAAACAGATTATTGTGATGAT & & 116905454127393196620143456. BLASTQ1 & L22194 \\
\hline \multirow[t]{2}{*}{3} & F- CGGGGATCTGTTCTATGAAC & $113-123$ & $116905478415524139147575692 . B L A S T Q 4$ & L22195 \\
\hline & R- TGATTAGCTGGCTGAATGTCC & & & \\
\hline \multirow[t]{2}{*}{4} & F- CTTCACСТCTACTCCCCAGTCAA & $249-263$ & & \\
\hline & R- CCTCCGACAAAGGAATGTAGCCT & & & \\
\hline \multirow[t]{2}{*}{5} & F- GGACTCTACCAACTGAGCTACAAG & $158-180$ & 1169055480-2754351013010061.BLASTQ4 & L22197 \\
\hline & R- TGAAATGAAGCTAAAGCAATGC & & 116905572320334201049824418.BLASTQ4 & \\
\hline \multirow[t]{2}{*}{6} & F- CATAGTTCATTCACAATATGGCA & $136-150$ & 1169055815-9144185044168702.BLASTQ4 & L22198 \\
\hline & R-CATGGAGTCACAAAGAGTTGAA & & $116905593619418188187125502 . B L A S T Q 4$ & \\
\hline \multirow[t]{2}{*}{9} & F- AGAGGATCTGGAAATGGAATC & 119-143 & & \\
\hline & R- GCACTCTTTTCAGCCCTAATG & & 1169056180-2112131702207315.BLASTQ4 & L22201 \\
\hline
\end{tabular}

a 1-5, Arevalo et al (1994); 6 and 9, Bhebhe et al (1994). 


\section{STATISTICAL ANALYSIS}

It was performed with the Cervus Software (Field Genetics, Ltd. UK), appropriate for high scale paternity analyses using codominant loci to generate interpretable results of the genetic comparison of many putative parents with many kids. Paternity is assigned to the most probable candidates with a predetermined confidence level. From the allelic frequencies obtained, paternity exclusion analysis was performed for the whole herd as well as for the Nubia and Boer groups using the following data for each locus: number of typed individuals (n), number of alleles for a given locus $(\mathrm{k})$, number of heterozygous individuals (Hets), number of homozygous individuals (Homs), observed heterozygosity (HO), expected heterozygosity (HE), polymorphic information content (PIC), exclusion power for each parent (Excl1, Excl2), and total exclusion power (EP).The following definitions are useful for the interpretation of results: PIC, Polymorphic information content: discriminatory power of loci considering allele number and relative frequency; values range from 0 (monomorphic) to 1 (highly discriminative) with numerous alleles of similar frequencies. Excl1, total exclusion power with data from a given parent. Excl2, total exclusion power with data from the given parents. HE, Expected heterozygosity: predicted by Hardy-Weinberg law. Hets, Heterozygotes: number of typed individuals with two different alleles for a given locus. HO, Observed heterozygotes: number of heterozygous individuals divided by the total number of individuals typed for a given locus. Homs, Homozygotes: number of typed individuals with identical alleles for a given locus. $\mathrm{k}$, Number of alleles found in a given locus. $\mathrm{n}$, Number of genotyped individuals.

Based on the allelic frequencies for each locus, two types of exclusion probability may be calculated: with one already known parent and without one already known parent.

\section{RESULTS}

A typical electropherogram exemplifying the allele patterns of a SRCRSCP locus in two different female-male-kid trios is shown in figure 1 , which shows the locus 6 allele of two Boer trios in which the male and female parents are either identical (trio 5) or different (trio 7) allele patterns.

An analysis of the polymorphism based on the amplified alleles of the SRCRSP-1, -2, -3, -4, -5, -6 and -9 loci is shown in tables 2 and 3. Thirty six alleles of the seven loci were amplified in the total herd (table 2), the length range was 114-216 bp with six alleles amplified of locus 1 (range: 133-165 bp), five alleles of locus 2 (range:145-169), four alleles of locus 3 (range: 114-132), five alleles of locus 4 (range: 184-216), five alleles of locus 5 (range: 158-185), six alleles of locus 6 (range: 141-169) and five alleles of locus 9 (table 3). Average values for heterozygosity and

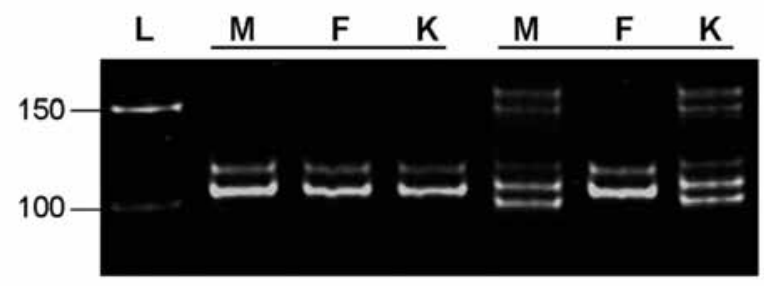

Figure 1. Alleles of Boer male-female- offspring(M-F-K) trios 7 and 5 amplified with the SRCRSP 6 primer set separated by electrophoresis in a polyacrylamide gel. Lane L, 50 bp ladder (position of 150- and 100-bp markers indicated to the left). Left M-F-K samples: Boer trio 7. Right M-F-K samples: Boer trio 5.

Alelos de padre-madre-cría en Boer (M-F-K) de los tríos Boer 7 y 5 amplificados con el juego de iniciadores SRCRSP 6, separados por electroforesis en un gel de poliacrilamida. Carril L, escalera con marcadores de $50 \mathrm{pb}$ (posiciones de los marcadores de 150- y 100-pb indicadas en el extremo izquierdo). Muestras M-F-K de la izquierda: trío 7 Boer 7. Muestras M-F-K de la derecha: trío 5 Boer.

Table 2. Alleles of the seven SRCRSP loci amplified in the total herd. Alelos de los siete loci SRCRSP amplificados en el rebaño total.

\begin{tabular}{lllllll}
\hline Loci $^{\mathrm{a}}$ & \multicolumn{5}{c}{ Alleles $^{\mathrm{b}}$} \\
\hline 1. (GT)24 & $\mathbf{1 . 1 3 3}^{\mathrm{c}}$ & 1.141 & 1.146 & 1.152 & 1.158 & $\mathbf{1 . 1 6 5}^{\mathrm{d}}$ \\
2. (TG)15TGG(TG)2 & 2.145 & 2.152 & $\mathbf{2 . 1 5 7}^{\mathrm{d}}$ & 2.163 & 2.169 & \\
3. (TG)6(TA)2(TG)11TT(GT)3 & $\mathbf{3 . 1 1 4}^{\mathrm{c}}$ & $\mathbf{3 . 1 1 9}^{\mathrm{d}}$ & 3.124 & $\mathbf{3 . 1 3 2}^{\mathrm{d}}$ & & \\
4. (GT)17 & 4.184 & 4.194 & 4.199 & 4.208 & 4.216 & \\
5. (AT)4(GT)16AT(GT)3 & 5.158 & 5.165 & 5.175 & 5.179 & 5.185 & \\
6. (GT)15 & $\mathbf{6 . 1 4 1}^{\mathrm{c}}$ & 6.150 & $\mathbf{6 . 1 5 4}^{\mathrm{d}}$ & 6.158 & $\mathbf{6 . 1 6 2}^{\mathrm{c}}$ & 6.169 \\
9. (GT)5(CA)16CG(CA)3 & $\mathbf{9 . 1 2 4}^{\mathrm{d}}$ & 9.130 & $\mathbf{9 . 1 3 6}^{\mathrm{d}}$ & 9.140 & 9.145 & \\
\hline
\end{tabular}

a The initial number in the name of each locus followed by a point corresponds to that of the SRCRSP oligonucleotide set used for its amplification.

b Allele names are formed with the locus number followed by a point and the average size (in $\mathrm{pb}$ ) of the PCR product. Bold letters indicate alleles amplified only in either the Nubia or Boer animals included.

Alleles amplified only in the Nubia group.

d Alleles amplified only in the Boer group. 
Table 3. Statistical analysis for paternity exclusion using all seven SRCRSP loci amplified in the total herd (T) and the Nubia (N) and Boer (B) groups. (N) y Boer (B).

Análisis estadístico para exclusión de paternidad usando los siete loci SRCRSP amplificados en el rebaño total (T) y en los grupos Nubia

\begin{tabular}{|c|c|c|c|c|c|c|c|c|c|}
\hline Locus & Groups & $\mathrm{k}$ & Hets & Homs & $\mathrm{OH}$ & $\mathrm{EH}$ & PIC & Excl1 & Excl2 \\
\hline \multirow[t]{3}{*}{1} & $\mathrm{~T}$ & 6 & 20 & 0 & 1.000 & 0.821 & 0.770 & 0.425 & 0.604 \\
\hline & $\mathrm{N}$ & 4 & 9 & 0 & 1.000 & 0.673 & 0.565 & 0.215 & 0.362 \\
\hline & B & 6 & 11 & 0 & 1.000 & 0.831 & 0.764 & 0.417 & 0.596 \\
\hline \multirow[t]{3}{*}{2} & $\mathrm{~T}$ & 5 & 19 & 1 & 0.950 & 0.772 & 0.715 & 0.351 & 0.531 \\
\hline & $\mathrm{N}$ & 4 & 8 & 1 & 0.889 & 0.725 & 0.624 & 0.254 & 0.415 \\
\hline & B & 5 & 11 & 0 & 1.000 & 0.797 & 0.724 & 0.362 & 0.543 \\
\hline \multirow[t]{3}{*}{3} & $\mathrm{~T}$ & 4 & 19 & 1 & 0.950 & 0.765 & 0.699 & 0.324 & 0.499 \\
\hline & $\mathrm{N}$ & 2 & 8 & 1 & 0.889 & 0.523 & 0.372 & 0.122 & 0.186 \\
\hline & B & 3 & 11 & 0 & 1.000 & 0.628 & 0.519 & 0.180 & 0.312 \\
\hline \multirow[t]{3}{*}{4} & $\mathrm{~T}$ & 5 & 14 & 6 & 0.700 & 0.729 & 0.672 & 0.306 & 0.485 \\
\hline & $\mathrm{N}$ & 5 & 5 & 4 & 0.556 & 0.719 & 0.640 & 0.273 & 0.452 \\
\hline & B & 5 & 9 & 2 & 0.818 & 0.758 & 0.681 & 0.315 & 0.492 \\
\hline \multirow[t]{3}{*}{5} & $\mathrm{~T}$ & 5 & 19 & 1 & 0.950 & 0.742 & 0.680 & 0.312 & 0.488 \\
\hline & $\mathrm{N}$ & 4 & 9 & 0 & 1.000 & 0.765 & 0.674 & 0.299 & 0.473 \\
\hline & B & 5 & 10 & 1 & 0.909 & 0.740 & 0.659 & 0.295 & 0.467 \\
\hline \multirow[t]{3}{*}{6} & $\mathrm{~T}$ & 6 & 19 & 1 & 0.950 & 0.809 & 0.756 & 0.404 & 0.582 \\
\hline & $\mathrm{N}$ & 5 & 8 & 1 & 0.889 & 0.771 & 0.684 & 0.318 & 0.494 \\
\hline & B & 6 & 11 & 0 & 1.000 & 0.823 & 0.753 & 0.403 & 0.582 \\
\hline \multirow[t]{3}{*}{9} & $\mathrm{~T}$ & 5 & 19 & 1 & 0.950 & 0.753 & 0.693 & 0.326 & 0.505 \\
\hline & $\mathrm{N}$ & 3 & 9 & 0 & 1.000 & 0.627 & 0.505 & 0.176 & 0.299 \\
\hline & B & 6 & 10 & 1 & 0.909 & 0.745 & 0.662 & 0.300 & 0.471 \\
\hline \multirow[t]{3}{*}{ Averages } & $\mathrm{T}$ & 5.57 & 18.50 & 1.57 & 0.921 & 0.775 & 0.719 & $0.361^{\mathrm{a}}$ & $0.538^{\mathrm{b}}$ \\
\hline & $\mathrm{N}$ & 3.86 & 8.00 & 1.00 & 0.889 & 0.686 & 0.581 & $0.237^{\mathrm{c}}$ & $0.383^{\mathrm{d}}$ \\
\hline & B & 5.14 & 10.4 & 0.57 & 0.948 & 0.760 & 0.680 & $0.325^{\mathrm{e}}$ & $0.495^{f}$ \\
\hline
\end{tabular}

k: number of alleles for each locus. Hets, number of heterozygous individuals. Homs: number of homozygous individuals. OH: observed heterozigosity. EH: expected heterozigosity. PIC: polymorphic information content. Excl1 and Excl2: exclusion power of the first and second parent, respectively. Exclusion powers:

In the total herd: first parent $0.952^{\mathrm{a}}$; second parent, $0.995^{\mathrm{b}}$.

In the Nubia group: first parent $0.852^{\mathrm{c}}$; second parent $0.969^{\mathrm{d}}$.

In the Boer group: first parent $0.922^{\mathrm{e}}$; second parent $0.989^{\mathrm{f}}$.

polymorphic information content for the seven loci in the total herd were respectively 0.921 and 0.719 . Number of alleles per locus ranged from 4 to 6 in the total herd with an average of 5.57 alleles per locus (table 3 ).

Locus SRCRSP-1 was the most informative since it had the highest exclusion value for the second parent (0.604); the least informative was locus 4 with the lowest second parent exclusion value (0.485) and highest number $(n=6)$ of homozygous individuals. Average heterozygosity was lower for the Nubia individuals $(0.686)$ than for the Boer ones (0.748). In the case of a randomly selected kid in which the genotype of one parent is known, the combined power of the group of loci used to exclude the second parent of both breeds with certainty was 0.952 . The exclusion power was higher in the Boer group (0.922) as expected from its higher heterozygosity than for the Nubia group (0.852). Given the genotype of the second parent, the exclusion power was 0.995 for the total herd, 0.989 for the Boer group and 0.970 for the Nubia group (table 3).

The alleles amplified in only one of the two groups included in this work (boldface in table 2) may be useful as breed markers if these findings are confirmed in a larger number of individuals.

\section{DISCUSSION}

The lengths of the alleles for the SRCRSP loci that we could amplify coincide with those described by Arevalo et al (1994) and Bhebe et al (1994) except for locus SRCRSP-4, where we found five 184-216 bp alleles whereas Arevalo 
et al (1994) described four 249-263 bp alleles. Our results for locus SRCRSP-9 contrast with those of Luikart et al (1999) who amplified twelve 200-234 bp alleles whereas we amplified five smaller (122-145 bp) alleles (table 4); these differences may be due both to differences in the method used to size the alleles and in the genetic background of the animals included in our study.

The discrimination efficiency or exclusion power is the value that gives credibility to paternity analysis. In general, the exclusion power must be above $99 \%$ and the probability of coincidence must be less than $10^{-10}$. In populations with more than 20 individuals with low inbreeding levels these values are obtained using around eight markers. In flocks with high inbreeding up to 15 markers may be required. It is necessary to have confidence limits with an exclusion power higher that $95 \%$ for acceptable statistical parameters in the most disadvantaged populations (Marshall et al 1998, Luikart et al 1999).

Microsatellite alleles have been used to verify paternity in diverse animal species. Jakabova et al (2002) solved paternity in horses by using six microsatellite loci with an exclusion power of 0.9888. Morera et al (1999) developed a method with an accumulated exclusion power of 0.9200 with four microsatellite loci in dogs. Luikart et al (1999) obtained exclusion power values in the range of $0.99997-$ 0.99999 with 11 microsatellite markers in caprine livestock, higher than those of breeds with higher heterozygosity. Our method with seven SRCRSP microsatellite loci in a 20 animal-herd has an exclusion power value of 0.9949, high enough for paternity analysis in caprine livestock. The potency of this method could be increased by using a higher number of loci in the future.

It can be concluded that our method amplified 36 alleles from seven SRCRSP microsatellite loci (SRCRSP-1, -2, $-3,-4,-5,-6$ and -9$)$ and may be used for reliable identification of individuals and paternity assessment in goats.

\section{SUMMARY}

SRCRSP (Small Ruminant Collaborative Research Support Program) loci are polymorphic 100-300 base pair-long microsatellite sequences of repeated dinucleotides that can be amplified by the polymerase chain reaction (PCR). Alleles of a given locus are the PCR products of unique length amplified with a set of specific primers. SRCRSP loci have been used to identify individuals but not to assess paternity in goats. We have developed a method to assess caprine paternity by polymorphism analysis of SRCRSP loci in a herd of 20 goats from two breeds, nine Nubia and 11 Boer, respectively. Thirty six alleles were amplified: 6 SRCRSP-1; 5 SRCRSP-2; 4 SRCRSP-3; 5 SRCRSP-4; 5 SRCRSP-5; 6 SRCRSP-6 and 5 SRCRSP-9. Four alleles appeared only in the Nubia group and eight only in the Boer group. Polymorphism analysis led to a 0.995 certainty for correct exclusion of the second parent. The loci described in this work could be used to control goat paternity as well as to identify individuals.
Table 4. Number and size of SRCRSP alleles identified previously and in this work.

Número y tamaño de los alelos SRCRSP identificados previamente y en este trabajo.

\begin{tabular}{crcrcc}
\hline \multirow{2}{*}{ Locus } & \multicolumn{2}{c}{ Previous } & & \multicolumn{2}{c}{ This work } \\
\cline { 2 - 3 } \cline { 5 - 6 } & $\mathrm{n}$ & Range (bp) & & $\mathrm{n}$ & Range (bp) \\
\hline 1 & 10 & $130-150^{\mathrm{a}}$ & & 6 & $133-165$ \\
\hline 2 & 4 & $151-157^{\mathrm{a}}$ & & 5 & $145-169$ \\
\hline 3 & 4 & $110-124^{\mathrm{a}}$ & & 4 & $114-132$ \\
\hline 4 & 4 & $113-123^{\mathrm{b}}$ & & \\
\hline 5 & 4 & $249-263^{\mathrm{a}}$ & & 5 & $184-216$ \\
\hline 6 & 10 & $162-182^{\mathrm{a}}$ & & 5 & $158-185$ \\
\hline 9 & 9 & $164-180^{\mathrm{b}}$ & & \\
\hline & 9 & $136-150^{\mathrm{c}}$ & 6 & $141-169$ \\
\hline
\end{tabular}

${ }^{\text {a }}$ Luikart et al (1999).

${ }^{\mathrm{b}}$ Arevalo et al (1994).

c Bhebe et al (1994).

\section{REFERENCES}

Arbiza AS. 1986. Producción de caprinos. AGT Editor, México, Pp 47-74. Arevalo E, DA Holder, JN Der, E Bhebhe, RA Linn, F Ruvuna, SK Davis, JF Taylor. 1994. Caprine microsatellite dinucleotide repeat polymorphisms at the SRCRSP 1, SRCRSP 2, SRCRSP 3, SRCRSP 4, and SRCRSP 5 loci. Anim Genet 75, 202.

Bhebhe E, J Kogi, DA Holder, E Arevalo, JN Der, RA Linn, F Ruvuna, SK Davis, JF Taylor. 1994. Caprine microsatellite dinucleotide repeats polymorphisms at the SRCRSP 6, SRCRSP 7, SRCRSP 8, SRCRSP 9, and SRCRSP 10 loci. Anim Genet 25, 203.

Innis MA, HD Gelfand, JJ Sninsky. 1999. PCR applications: protocols for functional genomics. Academic Press, San Diego, USA, Pp 355-364.

Jakabova D, J Trandzik, J Chrastina, L Hudecova, E Zetochova, J Bulla, A Bugarsky, F Jakab, P Kozlik. 2002. Effectiveness of six highly polymorphic microsatellite markers in resolving paternity case in thoroughbred horses in Slovakia. Czech J Anim Sci 47, 497-501.

Luikart G, MP Biju-Duval, O Ertugrul, Y Zagdsuren, C Maudt, P Taberlet. 1999. Power of 22 microsatellite markers in fluorescent multiplex for parentage testing in goats (Capra hircus). Anim Genet 30, 431-438.

Marshall TC, J Slate, LEB Kruuk, JM Pemberton. 1998. Statistical confidence for likelihood-based paternity inference in natural populations. Mol Ecol 7, 639-655.

Morera L, DF de Andrés, M Barbancho, JJ Garrido, CJ Barba. 1999. Detección de la variabilidad genética por microsatélites en el Alano Español. Arch Zoot 48, 63-70.

Sambrook J, EF Fritsch, T Maniatis. 1989. Molecular cloning: a laboratory manual. Cold Spring Harbor, New York, USA.

Thrusfield J. 2007. Veterinary Epidemiology. $3^{\text {rd }}$ ed. Blackwell Science, London, UK, Pp 229-230. 